Araştırma Makalesi - Research Article

\title{
Düzenli Uzun Dalga Denkleminin Hiperbolik Tip Yürüyen Dalga Çözümleri
}

\author{
Hülya Durur ${ }^{*}$, Asıf Yokuş², Doğan Kaya ${ }^{3}$ \\ Geliş / Received: 04/03/2020 \\ Revize / Revised: 25/06/2020 \\ Kabul / Accepted: 30/06/2020
}

ÖZ

Bu çalışmanın temel amacı $\left(1 / G^{\prime}\right)$-açılım yöntemi kullanılarak Düzenli Uzun Dalga (RLW) denklemi için yürüyen dalga çözümlerini elde etmektir. Elde edilen çözümlerde sabitlere özel değerler verilerek 3 boyutlu, 2 boyutlu ve kontur grafikleri sunulmuştur. Bu grafikler Düzenli Uzun Dalga denkleminin özel bir çözümüdür ve denklemin durağan bir dalgasını temsil etmektedir. Bu makalede sunulan çözümleri ve grafikleri bulmak için bilgisayar paket programı kullanılmaktadır.

Anahtar Kelimeler- $\left(1 / G^{\prime}\right)$-Açılım Yöntemi, Düzenli Uzun Dalga Denklemi, Yürüyen Dalga Çözümü, Tam Çözüm.

1*Sorumlu yazar iletişim: hulyadurur@ardahan.edu.tr, http:// orcid.org/0000-0002-9297-6873

Ardahan Üniversitesi, Mühendislik Fakültesi, Bilgisayar Mühendisliği Bölümü, Ardahan, 75000, Türkiye.

2İletişim: asfyokus@yahoo.com, http:// orcid.org/0000-0002-1460-8573

Fırat Üniversitesi, Fen Fakültesi, Aktüerya Bölümü, Elazığ, 23100, Turkey.

3̇letişim: dkaya36@yahoo.com, http:// orcid.org/0000-0003-4773-1313

Istanbul Ticaret Üniversitesi, Matematik Bölümü, Üsküdar, İstanbul, Turkey. 


\title{
Hyperbolic Type Traveling Wave Solutions of Regularized Long Wave Equation
}

\begin{abstract}
The main goal of this study is to obtain the traveling wave solutions for Regularized Long Wave (RLW) equation by using $\left(1 / G^{\prime}\right)$-expansion method. By giving special values to the constants in the solutions obtained, 3D, 2D, and contour graphics are presented. These graphics are a special solution of the (RLW) equation, and they represent a stationary wave of the equation. A computer package program is used to find the solutions and graphics presented in this article.
\end{abstract}

Keywords- (1/G') -Expansion Method, Regularized Long Wave Equation, Traveling Wave Solution, Exact Solution. 


\section{INTRODUCTION}

Traveling wave solutions of nonlinear evolution equations (NLEEs) play an active role in applied mathematics and mathematical physics. Variety methods have been used to find the analytical solutions of such equations (NLDEs). Some of these are F-expansion technique [1], Laplace transform method [2], $\left(1 / G^{\prime}\right)$ expansion method [3-5], the residual power series method [6,7], modified exp -expansion function method [8-10], $\left(G^{\prime} / G\right)$-expansion method [11,12], Adomian's decomposition method [13], collocation method [14,15], sub equation method [16,17], Homotopy perturbation method [18], new sub equation method [19] and so on [28-35].

In this study, authors investigated the analytical solutions of the (RLW) equation. Consider the form of the (RLW) equation [20],

$$
u_{t}+u_{x}+a\left(u^{2}\right)_{x}-b u_{x x t}=0, \quad a, b \in R
$$

the function u searched here depends on the variables $x$ and $t$.

There are many studies in the literature on RLW equation. Some of the studies are as follows: Solitary wave solutions of the generalized RLW equation are obtained [21], solutions of generalized RLW equation are obtained using variational iteration method [22], solutions of the one-dimensional (RLW) equation are obtained using a lumped Galerkin method based on quadratic B-spline finite elements numerical [23], approximate numerical solution for the nonlinear (RLW) equation are obtained applying adomian decomposition method [24], numerical solution of the one-dimensional (RLW) equation is obtained using linearized implicit finite difference method [25], the solution of the (RLW) equation is presented [26], and solitary wave solutions of the twodimensional RLW equation are obtained [27].

\section{II.MATERIAL AND METHOD}

\section{A. $\left(1 / G^{\prime}\right)$-Expansion Method}

We get general form of NLPDEs

$$
\sigma\left(u, \frac{\partial u}{\partial t}, \frac{\partial u}{\partial x}, \frac{\partial^{2} u}{\partial x^{2}}, \ldots\right)=0 .
$$

Here, let $u=u(x, t)=u(\xi), \quad \xi=k x+w t$, where $k, w$ are constants. We can be converted into the following nonlinear ODE for $u(\xi)$ :

$$
F\left(u, u^{\prime}, u^{\prime \prime}, u^{\prime \prime \prime}, \ldots\right)=0
$$

The solution of Eq. (3) is assumed to have the form

$$
u(\xi)=a_{0}+\sum_{i=1}^{n} a_{i}\left(\frac{1}{G^{\prime}}\right)^{i}
$$

where $a_{i}, \quad(i=0,1, \ldots, n)$ are constants, $n$ is a fixed number to be calculated by the principle of homogeneous balance according to the properties of each equation and $G=G(\xi)$ provides the following second-order IODE

$$
G^{\prime \prime}+\lambda G^{\prime}+\mu=0
$$


where $\lambda$ and $\mu$ are constants to be determined after,

$$
\frac{1}{G^{\prime}(\xi)}=\frac{1}{-\frac{\mu}{\lambda}+A \cosh [\xi \lambda]-A \sinh [\xi \lambda]},
$$

where $A$ is integral constant. If the desired derivatives of the Eq. (4) are calculated and substituting in the Eq. (3), a polynomial with the argument $\left(1 / G^{\prime}\right)$ is attained. An algebraic equation system is created by equalizing the coefficients of this polynomial to zero. The equation is solved using a package program and put into place in the default Eq. (3) solution function. Finally, the solutions of Eq. (1) are found.

\section{SOLUTIONS OF THE RLW EQUATION}

The traveling wave transmutation $\xi=k x+w t$, allows us to convert Eq. (1) into an ODE for $u=u(\xi)$,

$$
(k+w) u^{\prime}+2 a k u u^{\prime}-b k^{2} w u^{\prime \prime \prime}=0,
$$

integrating Eq. (7) once with respect to $\xi$ and by setting the integration constant to zero, we attain

$$
(w+k) u+a k u^{2}-b k^{2} w u^{\prime \prime}=0 .
$$

In Eq. (8), we achieve balancing term $n=2$ and in Eq. (4), the following situation is obtained:

$$
u(\xi)=a_{0}+a_{1}\left(\frac{1}{G^{\prime}}\right)+a_{2}\left(\frac{1}{G^{\prime}}\right)^{2}, \quad a_{2} \neq 0
$$

where $a_{1}$ and $a_{2}$ cannot be zero at the same time. Replacing Eq. (9) into Eq. (8) and the coefficients of the algebraic Eq. (1) are equal to zero, can attain the following algebraic equation systems

$$
\begin{aligned}
& \text { Const : } k a_{0}+w a_{0}+a k a_{0}^{2}=0, \\
& \left(\frac{1}{G^{\prime}[\xi]}\right)^{1}: k a_{1}+w a_{1}-b k^{2} w \lambda^{2} a_{1}+2 a k a_{0} a_{1}=0, \\
& \left(\frac{1}{G^{\prime}[\xi]}\right)^{2}:-3 b k^{2} w \lambda \mu a_{1}+a k a_{1}^{2}+k a_{2}+w a_{2}-4 b k^{2} w \lambda^{2} a_{2}+2 a k a_{0} a_{2}=0, \\
& \left(\frac{1}{G^{\prime}[\xi]}\right)^{3}:-2 b k^{2} w \mu^{2} a_{1}-10 b k^{2} w \lambda \mu a_{2}+2 a k a_{1} a_{2}=0, \\
& \left(\frac{1}{G^{\prime}[\xi]}\right)^{4}:-6 b k^{2} w \mu^{2} a_{2}+a k a_{2}^{2}=0 .
\end{aligned}
$$


When the resulting system Eq. (10) is solved by a package program or manually, we can present the following situations.

Case1.

$$
a_{0}=-\frac{b k^{2} \lambda^{2}}{a\left(1+b k^{2} \lambda^{2}\right)}, a_{1}=-\frac{6 b k^{2} \lambda \mu}{a\left(1+b k^{2} \lambda^{2}\right)}, a_{2}=-\frac{6 b k^{2} \mu^{2}}{a\left(1+b k^{2} \lambda^{2}\right)}, w=-\frac{k}{1+b k^{2} \lambda^{2}},
$$

replacing values Eq. (11) into Eq. (9) and we have the following hyperbolic type solution for Eq. (1)

$$
\begin{aligned}
& u_{1}(x, t)=-\frac{b k^{2} \lambda^{2}}{a\left(1+b k^{2} \lambda^{2}\right)}-\frac{6 b k^{2} \mu^{2}}{a\left(1+b k^{2} \lambda^{2}\right)\left(-\frac{\mu}{\lambda}+A \cosh \left[\lambda\left(k x-\frac{k t}{1+b k^{2} \lambda^{2}}\right)\right]-A \sinh \left[\lambda\left(k x-\frac{k t}{1+b k^{2} \lambda^{2}}\right)\right]\right)^{2}} \\
& -\frac{6 b k^{2} \lambda \mu}{a\left(1+b k^{2} \lambda^{2}\right)\left(-\frac{\mu}{\lambda}+A \cosh \left[\lambda\left(k x-\frac{k t}{1+b k^{2} \lambda^{2}}\right)\right]-A \sinh \left[\lambda\left(k x-\frac{k t}{1+b k^{2} \lambda^{2}}\right)\right]\right)} .
\end{aligned}
$$
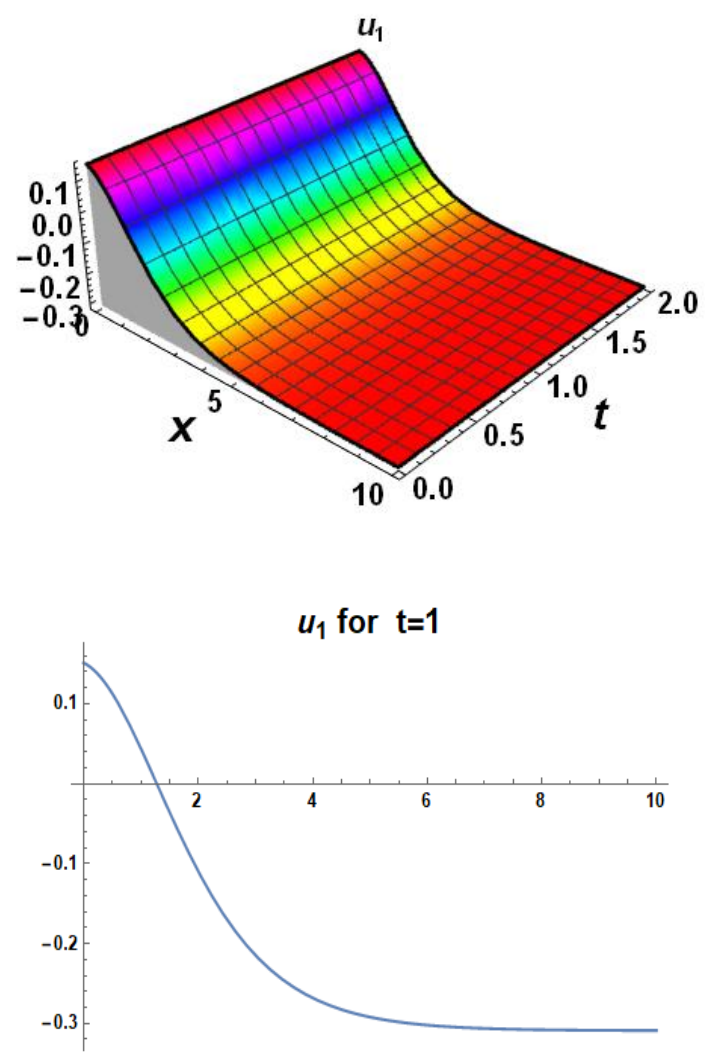


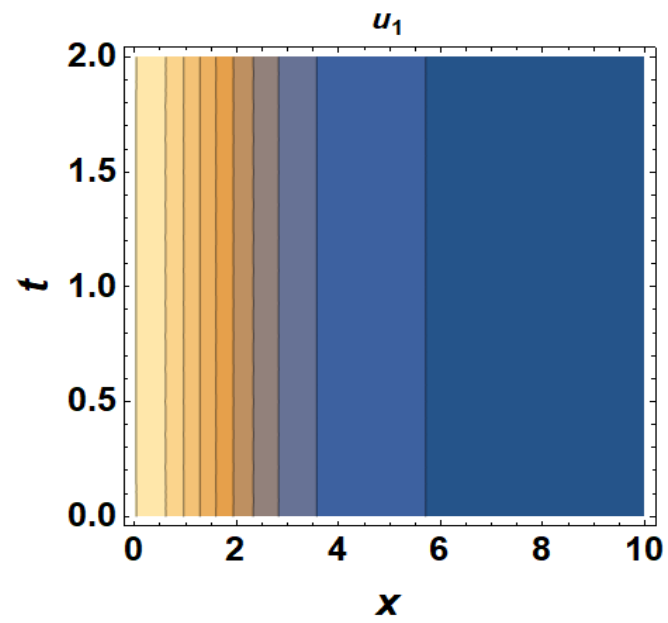

Figure 1. Respectively 3D, 2D, and contour graphics for $A=-2, b=2, k=3, \mu=1, \lambda=0.3, a=2, t=1$ values of Eq.(12).

\section{Case2.}

$$
a_{0}=0, a_{1}=\frac{6 \sqrt{b} \sqrt{w} \sqrt{k+w} \mu}{a}, a_{2}=\frac{6 b k w \mu^{2}}{a}, \lambda=\frac{\sqrt{k+w}}{\sqrt{b} k \sqrt{w}},
$$

replacing values Eq. (13) into Eq. (9) and we have the following hyperbolic type solution for Eq. (1):

$$
\begin{aligned}
u_{2}(x, t)= & \frac{6 b k w \mu^{2}}{a\left(-\frac{\sqrt{b} k \sqrt{w} \mu}{\sqrt{k+w}}+A \cosh \left[\frac{\sqrt{k+w}(t w+k x)}{\sqrt{b} k \sqrt{w}}\right]-A \sinh \left[\frac{\sqrt{k+w}(t w+k x)}{\sqrt{b} k \sqrt{w}}\right]\right)^{2}} \\
& +\frac{6 \sqrt{b} \sqrt{w} \sqrt{k+w} \mu}{a\left(-\frac{\sqrt{b} k \sqrt{w} \mu}{\sqrt{k+w}}+A \cosh \left[\frac{\sqrt{k+w}(t w+k x)}{\sqrt{b} k \sqrt{w}}\right]-A \sinh \left[\frac{\sqrt{k+w}(t w+k x)}{\sqrt{b} k \sqrt{w}}\right]\right)} .
\end{aligned}
$$



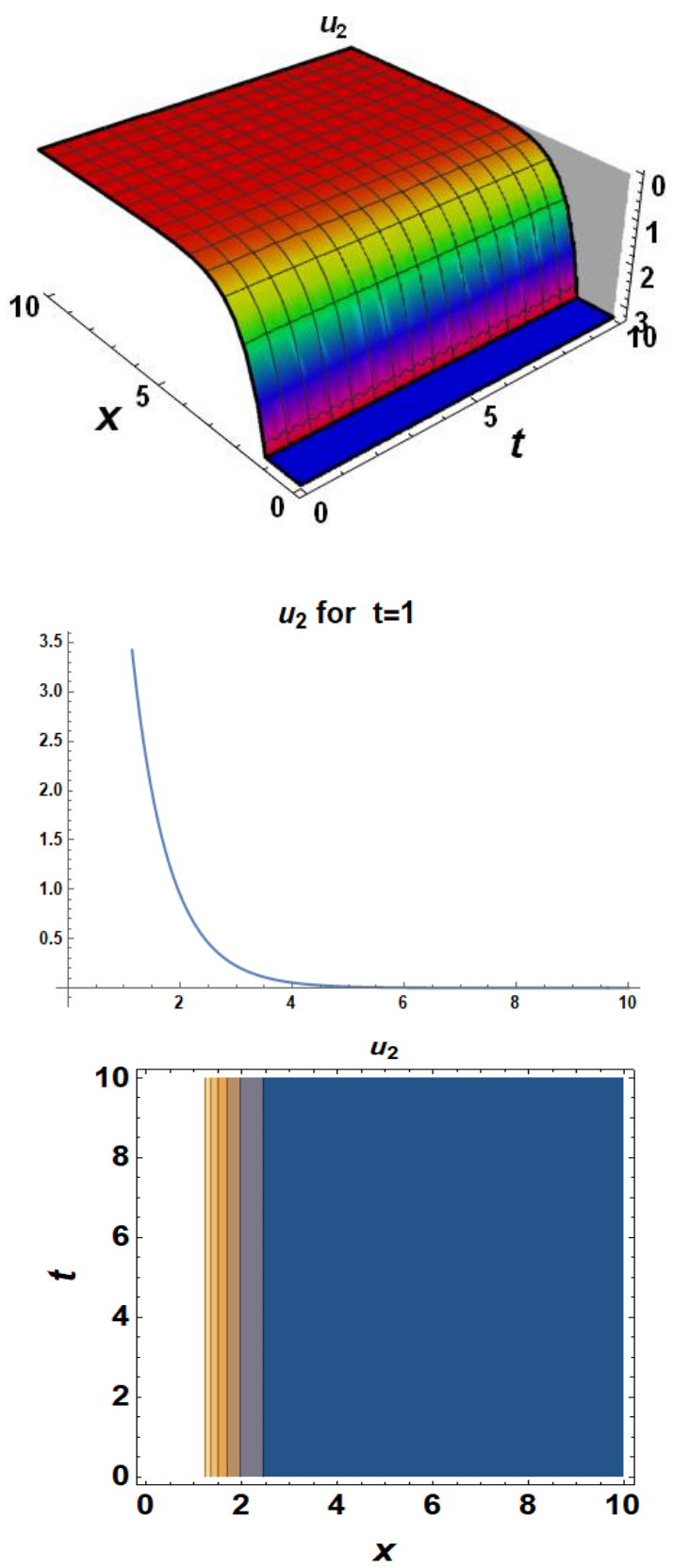

Figure 2. Respectively 3D, 2D, and contour graphics for $A=3, b=1, k=2, \mu=2, a=0.2, w=2, t=1$ values of Eq.(14).

\section{CONCLUSIONS}

In this paper, we obtain analytical solutions of RLW equation using $\left(1 / G^{\prime}\right)$-expansion method. 3D, 2D, and contour graphics are presented by giving special values to the constants in the obtained solutions. Each method offers solutions to nonlinear partial differential equations with different properties. It produces a hyperbolic solution function in the $\left(1 / G^{\prime}\right)$-expansion method. Solutions of this type have an important place especially in studies with shock wave structure and asymptotic behavior. This article shows that this method is efficient and practically suitable for applications in attaining analytical solutions for the RLW equation. With the aid of 
computer package program, we guarantee the correctness of the solutions found by returning them to the original equation. We hope it will be useful for other studies in applied sciences.

\section{REFERENCES}

[1] Silambarasan, R., Baskonus, H. M., \& Bulut, H. (2019). Jacobi elliptic function solutions of the double dispersive equation in the Murnaghan's rod. The European Physical Journal Plus, 134(3), 125.

[2] Faraj, B., \& Modanli, M. (2017). Using difference scheme method for the numerical solution of telegraph partial differential equation. Journal of Garmian University, 3, 157-163.

[3] Yokus, A., \& Yavuz, M. (2018). Novel comparison of numerical and analytical methods for fractional BurgerFisher equation. Discrete \& Continuous Dynamical Systems-S, 0.

[4] Yokuş, A., \& Durur, H. (2019). Complex hyperbolic traveling wave solutions of Kuramoto-Sivashinsky equation using $\left(1 / \mathrm{G}^{\prime}\right)$ expansion method for nonlinear dynamic theory. Balıkesir Üniversitesi Fen Bilimleri Enstitüsü Dergisi, 21(2), 590-599.

[5] Durur H., \& Yokuş, A. (1/G')-Açılım Metodunu Kullanarak Sawada-Kotera Denkleminin Hiperbolik Yürüyen Dalga Çözümleri. Afyon Kocatepe Üniversitesi Fen ve Mühendislik Bilimleri Dergisi. 2019; 19(3): 615-619.

[6] Durur, H., Şenol, M., Kurt, A., \& Taşbozan, O. Zaman-Kesirli Kadomtsev-Petviashvili Denkleminin Conformable Türev ile Yaklaş1k Çözümleri. Erzincan Üniversitesi Fen Bilimleri Enstitüsü Dergisi, 12(2), 796-806.

[7] Prakasha, D. G., Veeresha, P., \& Baskonus, H. M. (2019). Residual power series method for fractional SwiftHohenberg equation. Fractal and Fractional, 3(1), 9.

[8] Baskonus, H. M., Bulut, H., \& Atangana, A. (2016). On the complex and hyperbolic structures of the longitudinal wave equation in a magneto-electro-elastic circular rod. Smart Materials and Structures, 25(3), 035022 .

[9] Sulaiman, T. A., Bulut, H., Yokus, A., \& Baskonus, H. M. (2019). On the exact and numerical solutions to the coupled Boussinesq equation arising in ocean engineering. Indian Journal of Physics, 93(5), 647-656.

[10] Yokus, A., Baskonus, H. M., Sulaiman, T. A., \& Bulut, H. (2018). Numerical simulation and solutions of the two- component second order KdV evolutionarysystem. Numerical Methods for Partial Differential Equations, 34(1), 211-227.

[11] Durur, H. (2019). Different types analytic solutions of the (1+ 1)-dimensional resonant nonlinear Schrödinger's equation using $\left(\mathrm{G}^{\prime} / \mathrm{G}\right)$-expansion method. Modern Physics Letters B, 2050036.

[12] Khan, H., Barak, S., Kumam, P., \& Arif, M. (2019). Analytical Solutions of Fractional Klein-Gordon and Gas Dynamics Equations, via the $\left(\mathrm{G}^{\prime} / \mathrm{G}\right)$-Expansion Method. Symmetry, 11(4), 566.

[13] Kaya, D., \& Yokus, A. (2005). A decomposition method for finding solitary and periodic solutions for a coupled higher-dimensional Burgers equations. Applied Mathematics and Computation, 164(3), 857-864.

[14] Aziz, I., \& Šarler, B. (2010). The numerical solution of second-order boundary-value problems by collocation method with the Haar wavelets. Mathematical and Computer Modelling, 52(9-10), 1577-1590.

[15] Aziz, I., \& Asif, M. (2017). Haar wavelet collocation method for three-dimensional elliptic partial differential equations. Computers \& Mathematics with Applications, 73(9), 2023-2034.

[16] Durur, H., Kurt, A., \& Tasbozan, O. (2020). New Travelling Wave Solutions for KdV6 Equation Using Sub Equation Method. Applied Mathematics and Nonlinear Sciences, 5(1), 455-460. 
[17] Durur, H., Taşbozan, O., Kurt, A., \& Şenol, M. New Wave Solutions of Time Fractional KadomtsevPetviashvili Equation Arising In the Evolution of Nonlinear Long Waves of Small Amplitude. Erzincan Üniversitesi Fen Bilimleri Enstitüsü Dergisi, 12(2), 807-815.

[18] Yavuz, M., \& Ozdemir, N. (2018). Numerical inverse Laplace homotopy technique for fractional heat equations. Thermal Science, 22(Suppl. 1), 185-194.

[19] Kurt, A., Tasbozan, O., and Durur, H., The Exact Solutions of Conformable Fractional Partial Differential Equations Using New Sub Equation Method. Fundamental Journal of Mathematics and Applications, 2(2), 173-179, (2019).

[20] Kabir, M. M., Borhanifar, A., \& Abazari, R. (2011). Application of (G' G)-expansion method to Regularized Long Wave (RLW) equation. Computers \& Mathematics with Applications, 61(8), 2044-2047.

[21] Kaya, D. (2004). A numerical simulation of solitary-wave solutions of the generalized regularized long-wave equation. Applied Mathematics and Computation, 149(3), 833-841.

[22] Soliman, A. A. (2005). Numerical simulation of the generalized regularized long wave equation by He's variational iteration method. Mathematics and Computers in Simulation, 70(2), 119-124.

[23] Esen, A., \& Kutluay, S. (2006). Application of a lumped Galerkin method to the regularized long wave equation. Applied Mathematics and Computation, 174(2), 833-845.

[24] El-Danaf, T. S., Ramadan, M. A., \& Alaal, F. E. A. (2005). The use of adomian decomposition method for solving the regularized long-wave equation. Chaos, Solitons \& Fractals, 26(3), 747-757.

[25] Kutluay, S., \& Esen, A. (2006). A finite difference solution of the regularized long-wave equation. Mathematical Problems in Engineering, 2006.

[26] Dağ, İ. (2000). Least-squares quadratic B-spline finite element method for the regularised long wave equation. Computer Methods in Applied Mechanics and Engineering, 182(1-2), 205-215.

[27] Dehghan, M., \& Salehi, R. (2011). The solitary wave solution of the two-dimensional regularized long-wave equation in fluids and plasmas. Computer Physics Communications, 182(12), 2540-2549.

[28] Ahmad, H., Khan, T. A., Durur, H., Ismail, G. M., \& Yokus, A. (2020). Analytic approximate solutions of diffusion equations arising in oil pollution. Journal of Ocean Engineering and Science.

[29] Yokus, A. (2020). On the exact and numerical solutions to the FitzHugh-Nagumo equation. International Journal of Modern Physics B, 2050149.

[30] Yokus, A., Durur, H., Ahmad, H., \& Yao, S. W. (2020). Construction of Different Types Analytic Solutions for the Zhiber-Shabat Equation. Mathematics, 8(6), 908.

[31] Yokus, A., Durur, H., \& Ahmad, H. (2020). Hyperbolic type solutions for the couple Boiti-Leon-Pempinelli system. Facta Universitatis, Series: Mathematics and Informatics, 35(2), 523-531.

[32] Durur, H., \& Yokuş, A. (2020). Analytical solutions of Kolmogorov-Petrovskii-Piskunov equation. Balıkesir Üniversitesi Fen Bilimleri Enstitüsü Dergisi, 22(2), 628-636.

[33] Yokus, A., Kuzu, B., \& Demiroğlu, U. (2019). Investigation of solitary wave solutions for the (3+ 1)dimensional Zakharov-Kuznetsov equation. International Journal of Modern Physics B, 33(29), 1950350. 


\section{BŞEÜ Fen Bilimleri Dergisi}

7(2), 815-824, 2020

BSEU Journal of Science

DOI: $10.35193 /$ bseufbd.698820

[34] Modanli, M. (2019). On the numerical solution for third order fractional partial differential equation by difference scheme method. An International Journal of Optimization and Control: Theories \& Applications (IJOCTA), 9(3), 1-5.

[35] Yavuz, M. (2017). Novel solution methods for initial boundary value problems of fractional order with conformable differentiation. An International Journal of Optimization and Control: Theories \& Applications (IJOCTA), 8(1), 1-7. 